\title{
Study of maneuverability and behavior in the sea of the Light Cabotage and Logistics Support Vessel (BALC-L)
}

Estudio de maniobrabilidad y comportamiento en la mar del Buque de Apoyo Logístico y Cabotaje Liviano (BALC-L)

DOI: https://doi.org/10.25043/19098642.219

\author{
David Naranjo Tabares ${ }^{1}$ \\ José David Muñoz Ortega ${ }^{2}$ \\ Juan Manuel Valderrama Matallana ${ }^{3}$ \\ José María Riola Rodriguez ${ }^{2}$
}

\begin{abstract}
Colombia's hydrographic wealth is of great importance for the development of the economic sectors throughout the country, and together with neighboring countries such as Peru and Brazil, different needs arising from the difficult access to their more remote populations are shared. This is why, humanitarian missions are carried out through the ships of the Colombian Navy (ARC), which are at the service of the most remote civilian populations, providing, for example, response to disaster situations or covering logistics support. However, in the framework of these operations, problems have arisen due to the absence of having adequate vessels for navigation in shallow waters. To combat the problem, the ARC and the Administrative Department of Science, Technology and Innovation (MINCIENCIAS) have designated resources for Science and Technology Corporation for Naval, Maritime and Riverine Industry Development (COTECMAR) and Colombian Naval Academy (ENAP) to carry out research for the design of a new prototype vessel called BALC-L (Light Boat Logistic Support Vessel) that will meet the needs of logistics and disaster response. This paper focuses on studying and analyzing the behavior of the BALC-L ship in shallow waters, coastal areas and deep-water operations by means of numerical simulation, in order to know its movements and operational limitations under these conditions. This research presents a theoretical introduction, numerical simulation results and the validation of the data obtained from maneuverability and behavior at sea.
\end{abstract}

Key words: Maneuverability, seakeeping, numerical simulation, logistic support and coasting, river vessel.

\section{Resumen}

La riqueza hidrográfica de Colombia es de gran importancia para el desarrollo de los sectores económicos de todo el país, y junto a países vecinos como Perú y Brasil, se comparten diferentes necesidades derivadas del difícil acceso a sus poblaciones más alejadas. Por eso, las misiones humanitarias se realizan a través de los buques de la Armada de Colombia (ARC), los cuales están al servicio de las poblaciones civiles más remotas, brindando, por ejemplo, respuesta ante situaciones de desastre o cubriendo el apoyo logístico. Sin embargo, en el marco de estas operaciones han surgido problemas por no contar con embarcaciones adecuadas para la navegación en aguas poco profundas. Para combatir el problema, la ARC y el Departamento Administrativo de Ciencia, Tecnología e Innovación (MINCIENCIAS) han designado recursos para que la Corporación de Ciencia y Tecnología para el Desarrollo de la Industria Naval, Marítima y Fluvial (COTECMAR) y la Academia Naval de Colombia (ENAP) realicen investigaciones para el diseńo de una nueva embarcación prototipo denominada BALC-L (Light Boat Logistic Support Vessel) que satisfará las necesidades de logística y respuesta ante desastres. Este trabajo se centra en estudiar y analizar el comportamiento del buque BALC-L en aguas someras, zonas costeras y operaciones en aguas profundas mediante simulación numérica, con el fin de conocer sus movimientos y limitaciones operativas en estas condiciones. Esta investigación presenta una introducción teórica, resultados de simulación numérica y la validación de los datos obtenidos de maniobrabilidad y comportamiento en el mar.

Palabras claves: Maniobrabilidad, Navegación, simulación numérica, apoyo logístico y cabotaje, embarcación fluvial.

Date Received: April 15th, 2021 - Fecha de recepción: 15 de abril del 2021

Date Accepted: July 18th, 2021 - Fecha de aceptación: 18 de julio del 2021

\footnotetext{
${ }^{1}$ Escuela Naval de Cadetes "Almirante Padilla". Cartagena, Colombia. Email: david.467@hotmail.com

${ }^{2}$ Escuela Naval de Cadetes "Almirante Padilla”. Cartagena, Colombia. Email: josedavidmunozortega@gmail.com

${ }^{3}$ Escuela Naval de Cadetes "Almirante Padilla". Cartagena, Colombia. Email: juan.manuelv@hotmail.com

${ }^{4}$ Escuela Naval de Cadetes "Almirante Padilla". Cartagena, Colombia. Email: chema.riola@rga-psi.es
} 


\section{Introduction}

This research was developed with the purpose of carrying out a series of simulations of the maneuverability and behavior of the ship BALC-L within an R\&D from the Francisco José de Caldas, project bank which is being carried out between ENAP and COTECMAR. It is of vital importance for the Colombian Navy to be able to simulate in advance how the ship will behave before its construction takes place, in order to be able to propose improvements and avoid later transformations in its design which will result in costs and elongating the development phase of this project. Consequently, and given the vessel's operational purpose, communities in need located in the Colombian Pacific region will benefit from having a means of humanitarian aid when necessary.

The BALC-L class vessel is a ship that is in the design phase at the COTECMAR shipyard, which can be said to be a derivative version of the conventional BALC, but designed to have a shallower draft and access to places of difficult access through the rivers and therefore inner and remote parts of the country. In addition, it is designed to provide fast, flexible, modular and mobile logistical support and disaster relief, all this focused on the civilian population.

Thanks to studies carried out (Carreño, 2011) with vessels that operate using pump-jet propulsion system in shallow waters, mathematical models have been developed that take into account the NS or "Non-Squat" effect, which translates into an increase of the turning capacity in shallow areas (Clarke, 1998) (Eloot, 2013) for vessels with BALC-L characteristics. Traditionally, this effect has been studied in conventional vessels, being called "Squat effect" (Sierra et al, 2000), which depending on the Froude number (Escalante, 2010) of the vessel can generate the opposite effect to the one mentioned above, evidencing that by increasing the draft when the vessel reaches shallow waters, there is a considerable decrease in the maneuverability capabilities of these vessels (Herreros, 2000).

\section{Seakeeping}

The seakeeping behavior of a ship (Riola et al, 2017) is described by the balance equation, expressing the sum of the restoring moments that the ship will have, where it must be equal to the external force exerted on it (Medina, 2016).

$$
\begin{aligned}
& \sum_{k=1}^{6}\left[\left(M_{j k}+A_{j k}\right)\right] \\
& \left.\sum_{k=1}^{6}\left[\left(M_{j k}+A_{j k}\right)\right] \cdot \eta_{k}\left(B_{j k} \cdot \eta_{k}\right)+\left(C_{j k} \cdot \eta_{k}\right)\right] \\
& =F_{j} \cdot e^{-i \cdot w \cdot t}
\end{aligned}
$$

The behavior of vessels at sea (Vidal, 2008) is represented by the Amplitude Response Operators (RAO) (CEHIPAR, 2020), which give the vessel's responses to motion in regular waves and represent the transfer function of input (waves) and output (motion) being of total importance in determining the necessary parameters for the design of a vessel.

$$
R A O_{\text {pitch }}=\left(\frac{\theta_{0}}{\xi_{0}}\right)^{2} \quad R A O_{\text {roll }}=\left(\frac{\phi_{0}}{\xi_{0}}\right)
$$

Where the spectral crossover $(S z(w))$ is one of the most important aspects for these responses in irregular waves in space, and time where the sea spectrum $(S(w))$ is represented by the RAO or transfer function (France et al, 2001).

$$
S_{z}(w)=[R A O]^{2} . S(w)
$$

Fig. 1. BALC-L sailing.

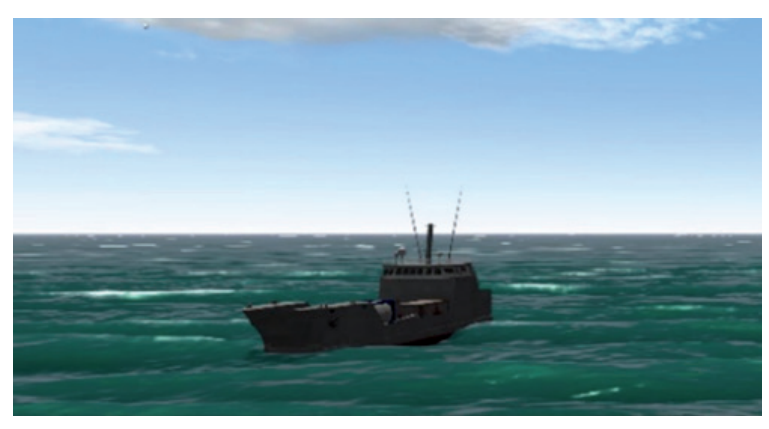

Source: CICEN Transas Simulator, 2020. 
The aim of this project is to study the behavior at sea of the BALC-L through a series of simulations with Maxsurf Motions Advanced of a 3D prototype provided by the shipyard. The shape plan and the hydrodynamic coefficients (Holtrop et al, 1978) of the ship were obtained in order to transfer them to the Maxsurf Motions Advanced program, in which the simulations were carried out by varying the speed with increments from knot to knot and course changes every $15^{\circ}$.

Tolater analyze the validation of the results obtained and full fill a greater characterization of the ship with the Transas full vision simulator of the Center for Research, Development and Innovations for Marine Activities (CIDIAM) of ENAP, a similar simulation was made in the Maxsurf program, varying the speed from 0 to 8 knots and the course every $15^{\circ}$, with the same conditions, however this simulator does not use only the shape plans but, takes advantage to complete the characteristics of the ship with the values extrapolated from those it has in its database of other ships. The idea is to determine the characteristics of interest of the ship and to propose its possible improvement for this purpose it was studied in 2 maritime conditions according to Douglas scale (Cazatormentas, 2019), as shown in Fig, 1.

The limit criteria defined by STANAG 4154 (NATO, 2000) for a patrol and transit vessel in its wheelhouse of $4^{\circ}$ RMS for rolling and $1.5^{\circ}$ RMS for pitching are used to study the ship's movements and accelerations.

Table 1. Seakeeping criteria of TAP.

\begin{tabular}{lr}
\hline TAP mission parameter & \multicolumn{1}{c}{ Limit value } \\
\hline Roll angle & $4,0^{\circ} \mathrm{RMS}$ \\
\hline Pitch angle & $1,5^{\circ} \mathrm{RMS}$ \\
\hline
\end{tabular}

The values obtained contribute to know if the vessel will be a risk for the safety of the ship, the habitability and comfort of the personnel, and the relevant operation of the equipment, systems and weapons, and thus contribute these results to this design that COTECMAR is carrying out in order to optimize the vessel to the maximum.

\section{Maneuverability}

Mathematical models (Carreño, 2011) (Riola et al, 2017) come, among other factors, from the need to economize the evaluation of vessels. They usually work in an inertial reference system whose center with coordinates is located at the point where the maneuver starts (Cipriano, 2009). And they generally require obtaining hydrodynamic derivatives by means of tests whose validation is subsequently performed with full-scale tests (Aláez, 1996). For three degrees of freedom, the following equations are considered (Cipriano, 2009):

$$
\begin{aligned}
& m(\dot{u}-v r)=X \\
& m(\dot{u}+u r)=Y \\
& I_{z}(\dot{r})=N
\end{aligned}
$$

These three differential equations express the respective forces and moments as seen from the inertial reference frame on the right side of each equation, while the left side presents the accelerations as seen from the body-centered, non-inertial reference frame (Inoue et al, 1981). To achieve this, the two reference systems are related by means of a transformation matrix (Carreño, 2011).

The forces and moments must be decomposed into the different factors that affect the maneuvers to be studied, in which the vessel must be subjected to the regulations reflected in resolution MSC.137 (76) (IMO, 2002). It is important to mention that one of the critical aspects to take into account in the preliminary design stage of a vessel that navigates in rivers with strong currents, is the level of control that can be expected of it, in the horizontal plane, when navigating, which is known as its behavior or maneuverability. This can also be defined as the percentage of efficiency in achieving a certain position of the bow of a boat with respect to a defined space (Sagarra, 1998).

For the Society of Naval Architects and Marine Engineers (SNAME) not only maneuverability should be studied, but also controllability, taking into account that in order to define maneuverability the human factor should be taken into account. 
Fig. 2. Warship undergoing maneuverability tests.

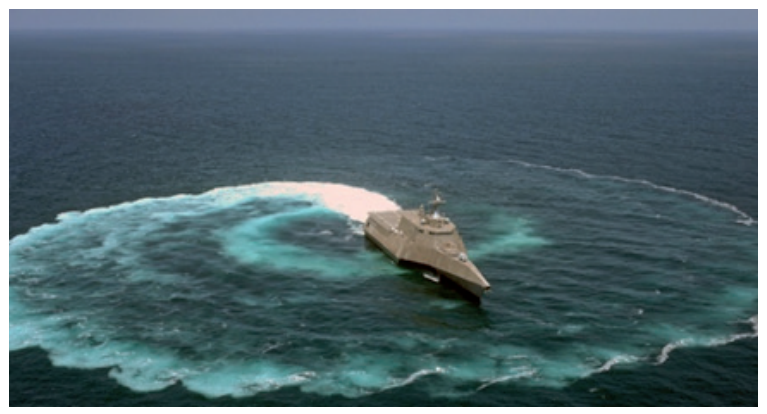

Source: Defense one website, (2016).

Since many of the critical maneuvers of warships are operated manually, which makes it difficult to determine. In the present research, the term maneuverability is used from a safety point of view (Sukas et al, 2019) (Aoki et al, 2006), taking into account the importance of the vessel's own shapes, which is especially critical in our case, given the shallow draft required for the vessel to be able to go up rivers as high as possible.

Due to this situation, maneuverability has gained importance in recent years, to such an extent that different international organizations

interested in maximizing efficiency maritime transport, trying to avoid material losses and mainly to protect the lives of crew members and passengers, have made great efforts to standardize regulations to assess the maneuverability of most vessels in most cases. These include the International Maritime Organization (IMO, 2002), the European Parliament, the Council of the European Union and the Russian River Registry (Carreño, 2011).

In our study and in order to carry out the maneuverability tests to the BALC-L in shallow waters, the mouth of the San Juan river has been simulated, for which it was necessary to compile the bathymetry of the river provided by the Center for Oceanographic and Hydrographic Research $(\mathrm{CIOH})$, the ship design data and the hydrodynamic theories related to the evaluation of the maneuverability of a warship. In order to carry out this maneuverability study, the
Maneuvering Simulation Laboratory (MANSIM) simulation program was used. The results were later validated with the Full Vision navigation simulator of Transas, owned by CICEN (ENAP's research center). Fig. 4 shows the virtual model of the BALC-L vessel navigating in the mouth of the San Juan river. This location was chosen because of its difficult maneuvering characteristics due to the strong currents and tides in the area.

Fig. 3. Virtual model of the BALC-L navigating in the mouth of the San Juan river.

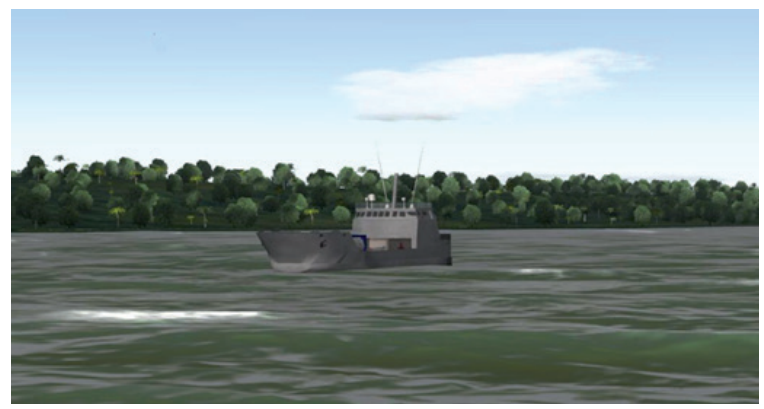

Source: CICEN full vision simulator.

\section{Results}

According to the proposed methodology, a model of the BALC-L was designed with the help of the Virtual Shipyard software to perform a validation of the results in ambient conditions in Simulator Transas. Thus, after performing the pertinent maneuverability validations in said program in deep waters, and the necessary adaptations to the propulsion with pump-jets, the model was taken to the virtual scenario of the river at the mouth of the San Juan River, in which two types of maneuvers were performed: evolutionary circles and zig-zag maneuvers.

The Fig. 5 shows the trajectory of the BALC-L, at the moment of executing an evolutionary circle maneuver at $35^{\circ}$ to starboard and a ZigZag maneuver at $20^{\circ}$, this was developed by the MANSIM maneuverability software, which was executed in this case in deep water conditions and with a propeller and rudder maneuvering system. 
Table 2. Specifies the use of each of the software and the conditions under which different maneuvers.

\begin{tabular}{|c|c|c|}
\hline $\begin{array}{l}\text { Maneuverability } \\
\text { Software }\end{array}$ & Conditions & Maneuvers executed \\
\hline MANSIM & $\begin{array}{l}\text { Maneuvering } \\
\text { with a } \\
\text { propeller and } \\
\text { rudder system. }\end{array}$ & $\begin{array}{l}\text {-Evolutive circle } 35^{\circ} \text { to } \\
\text { starboard } \\
\text {-Zig-Zag } 10^{\circ} \text { to } \\
\text { starboard } \\
\text {-Zig-Zag } 20^{\circ} \text {. } \\
\text { Maneuvering in deep } \\
\text { water conditions }\end{array}$ \\
\hline Virtual Shipyard & $\begin{array}{l}\text { Maneuvers } \\
\text { with a pump- } \\
\text { Jet propulsion } \\
\text { system. }\end{array}$ & $\begin{array}{l}\text { Maneuvering in deep } \\
\text { water conditions: } \\
\text {-Evolutionary circle } \\
35^{\circ} \text { to starboard. } \\
\text { Maneuvering in } \\
\text { shallow water } \\
\text { conditions: } \\
\text {-Evolutionary circle } \\
35^{\circ} \text { to starboard. }\end{array}$ \\
\hline Full Vision & $\begin{array}{l}\text { The maneuvers } \\
\text { in this } \\
\text { simulator were } \\
\text { performed } \\
\text { with a Jet } \\
\text { propulsion } \\
\text { system. }\end{array}$ & $\begin{array}{l}\text { Maneuvering according } \\
\text { to conditions in the } \\
\text { area of the mouth of } \\
\text { the San Juan River: } \\
\text {-Evolutionary circle } \\
35^{\circ} \text { starboard side } \\
\text {-Zig-Zag } 10^{\circ} \text { to } \\
\text { starboard } \\
\text {-Zig-Zag } 20^{\circ} \text {. }\end{array}$ \\
\hline
\end{tabular}

Source: Authors.

Fig. 4. Maneuvering trajectory of evolving circle 35 degrees to starboard and Zig-Zag 20 degrees, vessel with rudder and propeller propulsion, deep water condition.

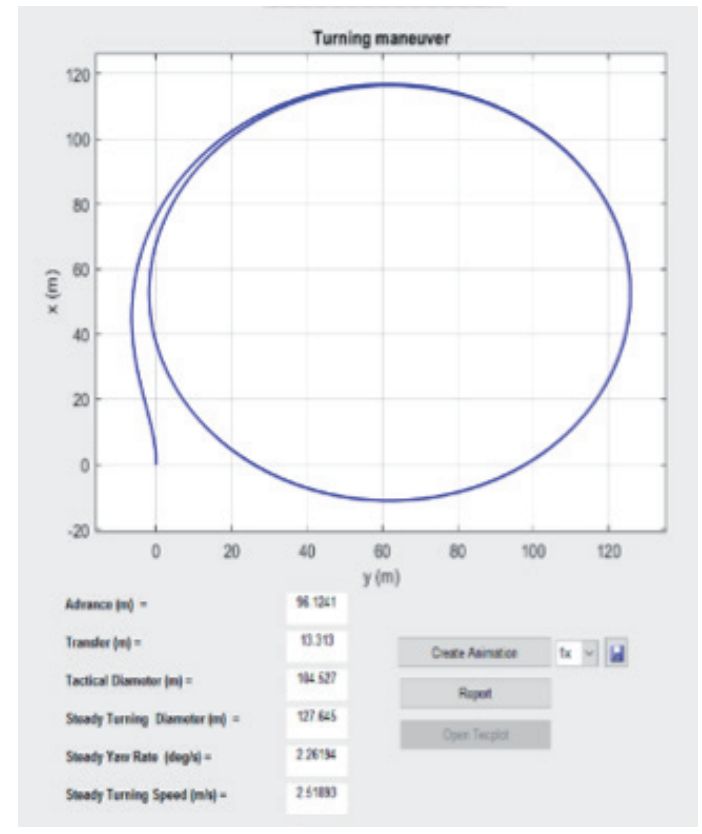

Source: Simulator MANSIM, 2019.
Fig. 5. Comparison between the 35-degree starboard evolving circle maneuver trajectory in shallow water and deep-water conditions.

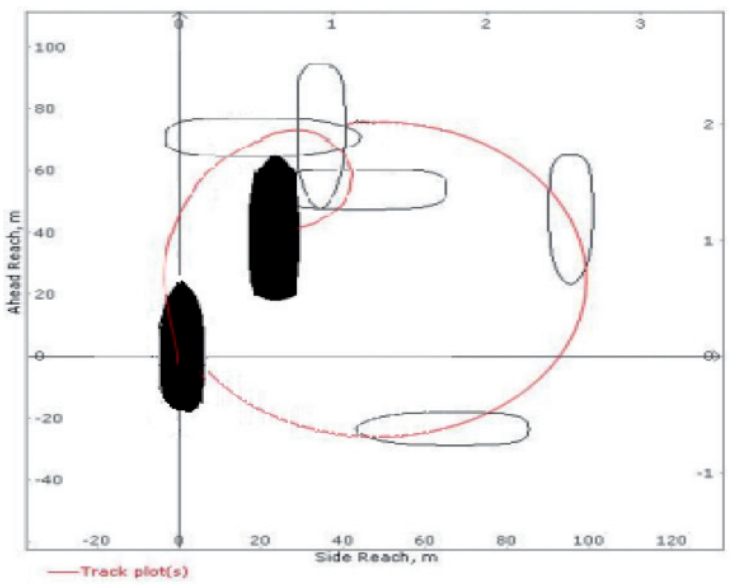

Source: Virtual Shipyard Software, 2020.

Table 3. Maneuverability result.

\begin{tabular}{|c|c|c|}
\hline VARIABLES & Deep waters & Shallow water \\
\hline Tactical Diameter & $90 \mathrm{~m}(2,54 \mathrm{~L})$ & $30,75 \mathrm{~m}(0,82 \mathrm{~L})$ \\
\hline Advance & $72,15 \mathrm{~m}(1,92 \mathrm{~L})$ & $64,25 \mathrm{~m}(1,71 \mathrm{~L})$ \\
\hline Transfer & $29,44 \mathrm{~m}(0,78 \mathrm{~L})$ & $18,4 \mathrm{~m}(0,49 \mathrm{~L})$ \\
\hline
\end{tabular}

Source: Authors.

The following graph shows the trajectory of the BALC-L, at the time of executing an evolutionary circle maneuver at 35 degrees to starboard,

Fig. 6. Evolutive circle maneuver $35^{\circ}$ to starboard at the mouth of the San Juan River.

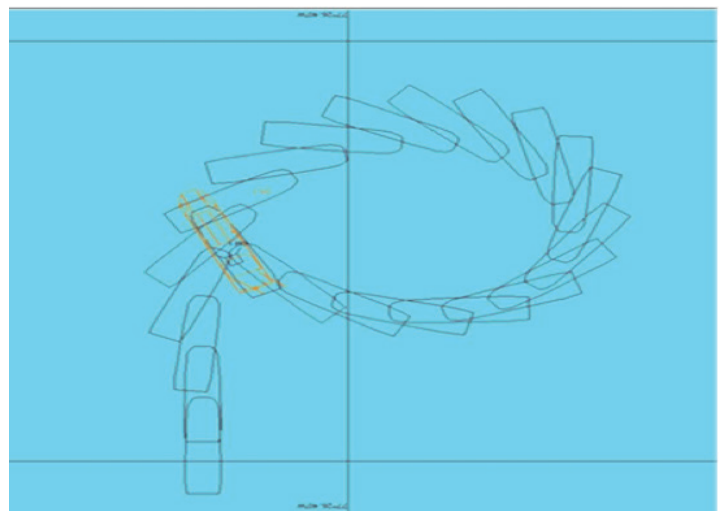

Source: Simulator Full Visión, 2020. 
this was developed by the Virtual Shipyard maneuverability software, which executed it in deep and shallow water conditions, with a pumpjet maneuvering system.

Table 4. Maneuverability results.

\begin{tabular}{|c|c|}
\hline VARIABLES & DATA \\
\hline Tactical Diameter & $111 \mathrm{~m}(2.70 \mathrm{~L})$ \\
\hline Advance & $104 \mathrm{~m}(2.6 \mathrm{~L})$ \\
\hline Transfer & $70.4 \mathrm{~m}(1.67 \mathrm{~L})$ \\
\hline
\end{tabular}

Source: Authors.

The following graph shows the trajectory of the BALC-L, at the time of executing an evolutionary circle maneuver at 35 degrees to starboard, this was developed by ENAP's Full Vision simulator, which was executed at the mouth of the San Juan river and with a pump-jet maneuvering system.

Fig. 7. Plot of course and rudder angle vs. time for Zigzag maneuver 10 and 20 degrees, pump jet propulsion vessel.

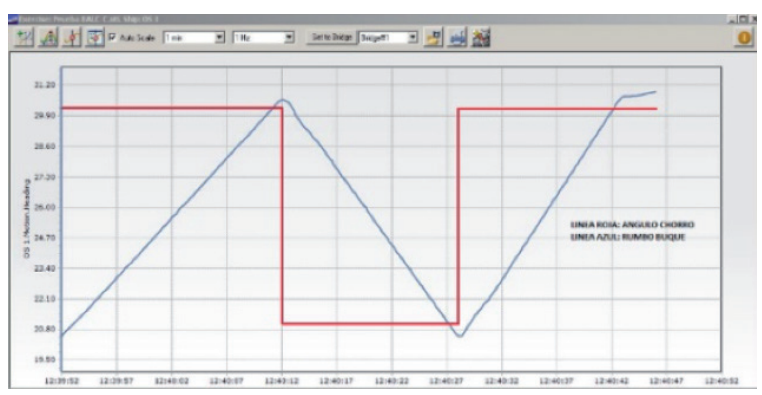

Source: Authors.

Table 5 below shows the relationship of course vs. rudder angle of the vessel when executing a zigzag maneuver $10^{\circ}$ and $20^{\circ}$, this was developed in the Full Vision simulator, which executed it at the mouth of the San Juan river and with a pump-jet maneuvering system.

According to these results, a verification was made with the IMO international maneuverability standards according to resolution MSC.137(76) (IMO, 2002) and NATO, in the publication "Guidance for naval surface ships mission oriented maneuvering requirements (ANEP-70)", in order to determine if the vessel complies with the requirements to be considered maneuverable. 2 shows the maneuvering criteria established.

Table 5. Overshoot angles in zig-zag maneuvers.

\begin{tabular}{|c|c|c|}
\hline $\begin{array}{l}\text { Overshoot } \\
\text { Angle }\end{array}$ & Zig-Zag $10^{\circ}$ & Zig-Zag $20^{\circ}$ \\
\hline $\begin{array}{l}\text { Overshoot } \\
\text { First Angle }\end{array}$ & 0.50 & 1.1 \\
\hline $\begin{array}{l}\text { Overshoot } \\
\text { Second Angle }\end{array}$ & 0.70 & 2.1 \\
\hline
\end{tabular}

Source: Authors.

Table 6. Maneuvering Criteria.

\begin{tabular}{|c|c|c|c|c|}
\hline \multirow[t]{2}{*}{ Maneuver } & \multirow[t]{2}{*}{ Units } & \multicolumn{2}{|c|}{$\begin{array}{l}\text { Criteria } \\
\text { proposed }\end{array}$} & $\begin{array}{c}\text { IMO } \\
\text { Requirements } \\
\end{array}$ \\
\hline & & $\begin{array}{l}\text { Transit } \\
\text { speed }\end{array}$ & $\begin{array}{l}\text { Low } \\
\text { speed }\end{array}$ & \\
\hline $\begin{array}{l}\text { Course } \\
\text { stability }\end{array}$ & Degrees & 4 & 4 & - \\
\hline $\begin{array}{l}\text { Evolution } \\
\text { circle }\end{array}$ & Lengths & 3 & 2 & 5 Lengths \\
\hline $\begin{array}{l}\text { Crash } \\
\text { Stop }\end{array}$ & Lengths & 10 & 10 & 15 Lengths \\
\hline Zig-Zag & Seconds & 7 & 10 & $\begin{array}{l}\text { Overshoot } \\
\text { Angle }\end{array}$ \\
\hline
\end{tabular}

Note: The table shows the comparison between NATO criteria and IMO requirements (NATO, 2001).

Fig. 8. "Comparison simulation of pitch $060^{\circ}$ RMS SS3 Maxsurf vs CIDIAM"..

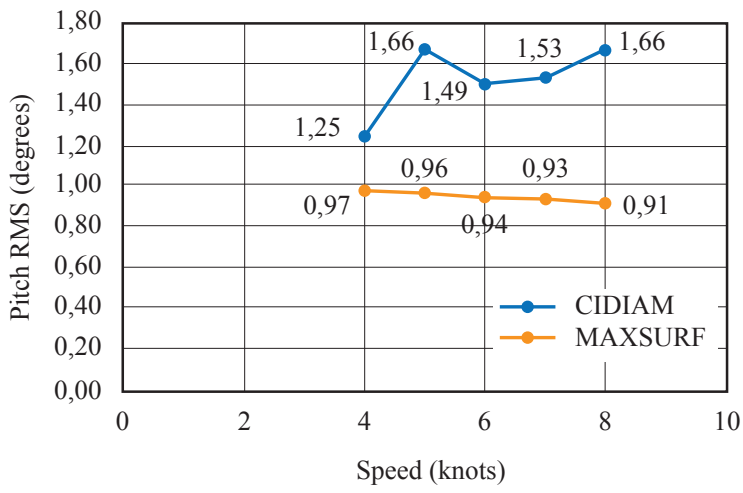

Source: Authors. 
In Fig. 8, data comparisons were made between the results of the Maxsurf Motions Advanced simulator and the CIDIAM full-vision simulator. At the $060^{\circ}$ heading the highest RMS values were given in the 2 simulators therefore, to compare the data it was evaluated for this heading when the wave has crashes on the port or starboard side of the vessel, meaning this will be at its maximum wave resonance and hence simulate as accurately as possible real sea conditions, where significant waves reach heights of $1.2 \mathrm{~m}$ with periods of $10 \mathrm{~s}$. This is the equivalent of this of this wave height found in the data that was supplied by the $\mathrm{CIOH}$, taken at a speed between 4 to 8 knots that are the values at which warships tend to sail.

\section{Conclusions}

- Despite its shallow draft, the BALC-L Vessel developed by COTECMAR, both in propeller and rudder propulsion and in pump jet propulsion, meets the maneuverability criteria contemplated by IMO and STANAG

- It is confirmed and validated that the turning diameter of the maneuver is reduced when the rudder angle is increased, and when the depth is lowered, improving considerably in shallow waters, such as those found in the San Juan River at the Colombian Pacific.

- When comparing the results obtained with the software used by CICEN, the MANSIM and virtual shipyard simulators (Zubaly, 1996) , a difference can be appreciated, however, the data of these mentioned sims are taken as an approximation and those of CICEN as the real validation. The results for both programs allow us to conclude that the BALC-L complies with the international standards mentioned above.

- Despite the good results obtained, the operational performance of the BALC-L cannot yet be assured, since the approach has been entirely theoretical and no use was made of scale models to perform tests with free or captive models in order to calculate its maneuvers with the degree of accuracy required by a ship of the Colombian Navy.

- By having a draft of $1.45 \mathrm{~m}$ and its hull forms almost flat, the vessel will not have a good performance at sea according to STANAG limits, as extracted from the results of the Maxsurf program as in the CIDIAM program, for neither of the 2 cases, however the vessel is in optimal conditions to be able to navigate in shallow waters.

- The vessel should navigate in open waters with swell less than SS3 for transit between river areas.

- With a sea state SS3 her minimum RMS pitch value were $1.49^{\circ}$ respectively allowing her to sail at a heading $060^{\circ}$ with a speed between 6 knots. This is the limit sea state in which the vessel will be able to sail but trying to avoid taking the waves other than by the bow or stern.

\section{References}

[1] ALÁEZ, J. A. (1996). Comportamiento del buque en la mar. Cátedra Jorge Juan. A Coruña: Universidad de da Coruña. España, 41-68.

[2] AOKI, I. et al. (2006). On the prediction method for maneuverability of a full-scale ship, Journal of the Japan Society of Naval Architects and Ocean Engineering., 3, 157-165.

[3] CARreÑO, J. E. (2011). Simulación de maniobras de buques con sistemas de propulsión no convencional en aguas poco profundas. Madrid: Universidad Politécnica de Madrid, España.

[4] Cazatormentas. (2019). La escala Douglas: conoce el oleaje y el estado del mar.

[5] CEHIPAR. (2020). Centro de experiencias Hidrodinámicas de El Pardo, www.cehipar. es/. (Recuperado 14 de noviembre de 2020) 
[6] CIPRIANO, W. (2009). Maniobrabilidad de Buques. Lima: Universidad Nacional de Ingeniería.

[7] CLARKE, D. (1998). The effect of shallow water on maneuvering derivatives using conformal mapping. Control Engineering Practice, Vol. 6, 629-634.

[8] ELOOT, K. (2013). Ship behavior in shallow and confined water: an overview of hydrodynamic effects through EFD. Amberes: NATO.

[9] Escalante, R. (2010). Incidencia de los movimientos verticales del buque en la determinación de la profundidad del canal. www.graduadosportuaria.com. ar/vias_Navegables/.pdf. (Recuperado 11 de noviembre de 2020).

[10] FRANCE, W., LEVADOU, M., TREAKLE, T., PAUlling, J., MICHEL, R., \& MOORE, C. (2001). An investigation of headsea parametric rolling and its influence on container lashing systems. SNAME Anual Meeting.

[11] HERREROS, M. (2000). El fenómeno squat en áreas de profundidad variable y limitada. Madrid: Universidad Politécnica de Madrid.

[12] HOLTROP, J., MENNEN, G. (1978). A statistical power prediction method. International Shipbuilding Progress, Vol. 25, No 290.

[13] IMO. (2002). Explanatory notes to the standards for ship maneuverability. Londres: IMO.www.imo.org/en/ KnowledgeCentre/IndexofIMOResolutions/ Maritime-Safety-Committee/Documents/ MSC.137\%2876\%29.pdf (Recuperado 6 de mayo de 2020).

[14] INOUE, S., HIRANO, M., \& KIJIMA, K., (1981). Hydrodynamic derivatives on ship maneuvering. International Shipbuilding Progress, Vol. 28, No 321, 112-125.
[15] LEE, H.Y., SHIN, S.S. (1998). The prediction of ship's maneuvering performance in initial design stage, Practical Design of Ships.

[16] MEDINA, C. M. (2016). Análisis de los aspectos operacionales y de comportamiento en olas en el diseño de embarcaciones de apoyo tipo PSV para el Caribe colombiano. Universidad Tecnológica de Bolivar, Cartagena, Colombia.

[17] NATO (2000). Common procedures for seakeeping in the ship design process. Standardization Agreement (STANAG 4154).

[18] RIOLA , J. M., PÉREZ, R., Y DÍAZ, J. J. (2017). El comportamiento en la mar de los modernos buques de guerra. Revista de Ingeniería Naval, 74-79.

[19] RIOLA, J., VELASCO, J. A., REVESTIDO, E., (2017). Estudio de Maniobrabilidad de un UUV. Madrid: Universidad Politécnica de Madrid, España.

[20] SAGARRA, R. (1998). Maniobra de los Buques. Ediciones UPC, España.

[21] SIERRA, M.A., RODRÍGUEZ, R., ROJAS, L. (2000). El fenómeno squat en áreas de profundidad variable y limitada. Universidad Politécnica de Madrid, Espańa.

[22] SUKAS, O.F., KINACI, O.K., BAL, S. (2019). System-based prediction of maneuvering performance of twin-propeller and twinrudder ship using a modular mathematical model. Applied Ocean Research, 84, 145-162.

[23] VIDAL, J. R. (2008). Teoría de las olas y comportamiento de la mar. www.studocu. com/es (Recuperado 2 de marzo de 2020).

[24] ZUBALY, R. (1996). Applied Naval Architecture. Centreville, Madriland: Coronell Maritime Press Architecture. 